\title{
НОВИЙ ПОГЛЯД НА ВИЗНАЧЕННЯ МОМЕНТУ ПЕРЕХОДУ ПРАВА ВЛАСНОСТІ ЗА ДОГОВОРОМ
}

Гудима М. М.

Ця наукова публікація присвячена аналізу законодавчого підходу та основних доктринальних положень щодо встановлення моменту переходу права власності на підставі договору, визначення їх теоретичної обгрунтованості та практичної ефективності. У роботі виявлено два основні підходи, притаманні правовим системам світу, до визначення моменту переходу права власності та визначено, якого підходу дотримується вітчизняне цивільне законодавство.

Проведено буквальне тлумачення змісту ч. 1 cm. 334 ЦК України, в тому числі проаналізований традиційний підхід до визначення моменту переходу права власності, який використовує вітчизняне законодавство «за замовчуванням», а також можливість відходу від нього за домовленістю сторін договору чи вказівкою законодавства. Оскільки законодавець прив'язує момент переходу права власності за договором до моменту передачі речі, в публікації виявлено місце та значення передачі у системі механізму переходу права власності.

Звернення до семантичного аналізу слів «передача», «передавати» та дослідження підходу до розуміння такого поняття у вітчизняному законодавстві посприяло формулюванню висновку, що прийняття та передача є двома самостійними поведінковими актами, що заклало сумніви в коректності прив'язки моменту переходу права власності до передачі (односторонньої діі) без зворотного акту прийняття. За результатами проведеного дослідження здійснено відхід від традичійного підходу до визначення моменту переходу права власності та запропоновано змістити акценти і визначити ним момент вчинення зустрічної діі контрагентом за безоплатним договором у вигляді прийняття речі та момент отримання зустрічного задоволення контрагентом за оплатним договором (наприклад, оплата ціни за річ за договором купівліпродажу, отримання речі взамін на іншу річ за договором міни тощо), що відповідатиме сутності та економічному значенню цивільного договору як основоположної підстави переходу права власності, сприятиме удосконаленню юридичної практики шляхом уникнення проблем, зумовлених переходом права власності до моменту прийняття речі чи отримання зустрічного задоволення іншою сторо-

(с Гудима М. М., 2020 ною та суперечок, пов'язаних з доведенням факту передачі речі і переходу права власності.

Ключові слова: момент переходу права власності, договір, передача речі, прийняття речі, зустрічне задоволення вимог.

Hudyma M. M. Anew look at determining the moment of transfer of ownership under the contract

This scientific publication is devoted to the analysis of the legislative approach and the main doctrinal provisions for establishing the moment of transfer of ownership on the basis of the contract, determining their theoretical validity and practical effectiveness. The paper identifies two main approaches inherent in the legal systems of the world to determine the moment of transfer of ownership and identifies which approach is followed by current domestic civil law.

A literal interpretation of the content of Part 1 of Art. 334 of the Civil Code of Ukraine is made, including the analysis of the traditional approach to determining the moment of transfer of ownership, which uses national law "by default", as well as the possibility of withdrawal from it by agreement of the parties to the contract or by law. Since the legislator binds the moment of transfer of ownership under the contract to the moment of transfer of the thing, the publication reveals the place and significance of the transfer in the system of the mechanism of transfer of ownership.

The reference to the semantic analysis of the words "transfer", "to transfer" and the study of the approach to understanding this concept by the national legislator, helped to formulate the conclusion that acceptance and transfer are two independent behavioural acts, which cast doubt on the correctness of linking the transfer of ownership to transfer (unilateral action) without a reverse act of acceptance. According to the results of the study, there was made a shift away from the traditional approach to determining the moment of transfer of ownership and proposed to shift the emphasis and determine the moment of consideration by the counterparty under the payment agreement (e.g., payment for the purchased item, receiving the item in exchange for another item under the contract), which will correspond to the essence and economic significance of the civil contract as a fundamental basis for the transfer of ownership, will improve legal practice by means of avoiding the problems caused by the transfer of ownership until the other party 
receives consideration and disputes related to the transfer of property and transfer of ownership.

Key words: moment of transfer of ownership, contract, transfer of property, acceptance of property, consideration of requirements.

Постановка проблеми та іï актуальність. Напевно, складно оспорити факт того, що принципово важливим є визначення моменту, з якого набувач речі за договором стає їі власником. Неодноразово влучно підкреслювалося в літературі, що точне визначення моменту набуття права власності гарантує належний захист інтересів кредиторів, а також фіскальні інтереси держави, тому що дозволяє визначити склад майнової маси суб'єкта права [1, с. 57]. Точне встановлення моменту набуття права власності у набувача майна за договором має істотне практичне значення, оскільки саме з цього моменту до набувача переходить і тягар утримання майна (ст. 322 Цивільного кодексу України) (далі - ЦК), і ризик випадкового знищення та випадкового пошкодження (псування) майна (ст. 323 цК України) [2, с. 42]. Зрештою, підсумовує Ю.В. Шибаєва, саме володіння об'єктами на праві власності і ясність щодо осіб, які мають таке право, забезпечують стабільність у соціальних і економічних відносинах [3, с. 4].

Проте, попри неоспорювану практичну значимість чіткості визначення моменту переходу права власності за договором, вирішення вказаного питання просте тільки на перший погляд. Насправді, питання про те, коли ж відбувається перехід права власності за договором, з огляду на достаток договірних типів, іноді вирішується доволі неоднозначно та і загальний законодавчо закріплений підхід до визначення вказаного моменту, на наш погляд, $є$ недосконалим, що потребує чергового звернення до вказаної проблематики та перегляду наявних догм у відповідній царині.

Аналіз останніх досліджень і публікацій. Проблематика переходу речових прав за договором перебувала в колі наукових інтересів і періодично висвітлювалася у працях низки вітчизняних та зарубіжних дослідників: Т.В. Боднар, Л.Ю. Василевської, О.В. Дзери, І.О. Ємелькіної, Р.А. Майданика, М.Л. Пятова, К.І. Скловського, І.В. Спасибо-Фатєєвої, О.А. Сурженка, Д.О. Тузова, Є.О. Харитонова, Г.Г. Харченка, Ю.В. Шибаєвої, Я.М. Шевченко, Г.Ф. Шершеневича, О.О. Щипанової, О.С. Яворської та інших. Разом із тим питання визначення моменту переходу права власності до набувача за договором досліджувалося відокремлено в межах спеціальних публікацій нечасто. Таку ситуацію частково можна пояснити наявністю чіткого законодавчого вирішення цього питання в межах відповідних норм Цивільного кодексу України. Тому недосконалість законодавчого підходу та недостатня дослідженість питання визначення моменту переходу права власності за договором, попри іï очевидну значимість, і обґрунтовують актуальність тематики цієї публікації.

Мета публікації полягає у здійсненні аналізу законодавчого підходу та основних доктринальних положень щодо встановлення моменту переходу права власності на підставі договору, визначення ïх теоретичної обґрунтованості та практичної ефективності.

Виклад основного матеріалу. Вирішення питання про те, коли відбувається перехід права власності у зв'язку з укладеним договором було та й нині $\epsilon$ доволі неоднозначним для різних правових систем у різні історичні періоди. Так, Л.Б. Забелова, Д.А. Ястребов відзначають, що в деяких державах право власності переходить від продавця до покупця з моменту укладення договору, коли товари індивідуалізовані в договорі (Італія, Данія та інші країни, що запозичили принципи та ідеї французького права), тоді як інший підхід виходить з того, що право власності на товар переходить до покупця лише з передачею такого товару, застосовується в праві ФРН, Швейцарії, Нідерландів, Греції, Іспанії, Бразилії [4, с. 48]. Тобто залежно від системи права сформувалися два підходи: консенсуальна система (перехід права власності вже в момент укладення договору) і система «традиції» (від латинського - «передача») (необхідною, окрім укладення договору, $\epsilon$ і фактична передача речі покупцю) [5, с. 32-33]. І в континентальній правовій системі, зауважує О.О. Щипанова, історично склалися два вищевказані підходи: романський, за якого право власності на річ за договором переходить до набувача в момент укладання договору, та германський - в основу якого покладено принцип традиції, опрацьований ще стародавнім римським правом: “Traditionibus...dominia rerum, non nudis pactis transferuntur" - право власності на речі переноситься за допомогою передачі,.. а не голих угод (С.2.3.20) [2, с. 42].

У сучасній вітчизняній науці цивільного права «за замовчуванням» застосовується підхід, за якого право власності у набувача речі за договором виникає з моменту іï передачі, про що свідчить положення ч. 1 ст. 334 цК України: «Право власності у набувача майна за договором виникає з моменту передання майна, якщо інше не встановлено договором або законом». 
Визначаючи місце передачі у системі механізму переходу права власності, відзначимо, що ми не підтримуємо позицію абсолютизації значення передачі речі для виникнення права власності та розгляду ï як самостійного правочину (речового договору), відірваного від договору зобов'язального. Ми схиляємося до того, що передача речі чи інші фактичні дії щодо виконання договору $\epsilon$ важливою частиною складного юридичного складу договору. Таку позицію висловлювали ще такі корифеї цивілістики, як Д.М. Генкін та І.Б. Новицький. Так, наприклад, Д.М. Генкін підкреслював, що «для наявності угоди може бути необхідно не тільки волевиявлення, а й реальна дія (наприклад, передача речі)» [6, с. 213]. І.Б. Новицький вказував, що складний склад угоди може включати угоду сторін і фактичну передачу речі $[7$, с. 16]. Цілком слушною $\epsilon$ позиція Ю.В. Шибаєвої, яка відзначає, що наявна залежність договору як підстави передачі і самої передачі, бо передача відбувається не в результаті простого волевиявлення про це, а як результат попередньої домовленості про вчинення різних дій, у тому числі і про передачу [3, с. 46]. Аналіз положень російського законодавства (ст.ст. 223, 224 Цивільного кодексу Російської Федерації), аналогічних вітчизняним нормам, привів дослідницю до висновку, що традиція в них вказується як технічний елемент взаємодії, так само як, наприклад, передача доданої до обладнання документації, але не як дії, що сама собою викликає встановлення, зміну або припинення правовідносин; поява права власності приурочена до традиції, але не викликається іï силою, передача тут виконує обслуговуючу роль [3, с. 51]. Подібного висновку дійшов О.А. Сурженко, проаналізувавши формулювання нормативних положень вітчизняного законодавства. Науковець пише, що з огляду на те, що норма про передання як вручення майна міститься у статті, що має назву «Момент набуття права власності за договором», виходить, що саме договір і $\epsilon$ підставою набуття права власності, а передання майна (його вручення) - дія на виконання цього договору [8]. Справді, видається, що саме на такій догмі і базується підхід вітчизняного законодавця, який приурочив момент переходу права власності до передачі речі, проте із застереженням щодо наявності та дійсності договору про перехід права власності.

Буквальний сенс вищезгаданої статті 334 ЦК України формулює таке правило: «Право власності у набувача майна за договором виникає з моменту передання майна, якщо інше не встановлено договором або законом». Отже, аналіз такого формулювання вказує на диспозитивність норми та можливість відходу від правила в ній, сформульованого за вказівкою законодавця, визначеною у спеціальній нормі або за домовленістю сторін договору, які можуть змінити момент переходу права власності, прив'язавши його до інших обставин.

Так, інше правило щодо визначення моменту переходу права власності на річ, аніж визначене в ЦК України, міститься у Законі України «Про приватизацію державного та комунального майна». Частина 6 ст. 25 цього законодавчого акта вказує, що право власності на об'єкт приватизації переходить до покупця після сплати в повному обсязі ціни продажу об'єкта разом з неустойкою (у разі іiі нарахування), крім випадків переходу права власності на пакет акцій. Право власності на придбаний пакет акцій переходить до покупця після повної сплати ціни продажу разом з неустойкою (у разі iї нарахування) за пакет акцій та з моменту зарахування пакета акцій на рахунок у цінних паперах покупця у депозитарній установі. Право власності на об'єкт приватизації переходить до покупця не раніше дати отримання дозволу Антимонопольного комітету України на концентрацію, якщо отримання такого дозволу вимагається законом [9]. Видається, що на таке положення слід звернути особливу увагу, і не лише в ключі зміни диспозитивного правила щодо зумовленості моменту переходу права власності моментом передачі речі, встановленого ЦК України, а й з точки зору його логічності та практичної корисності, про що йтиметься далі.

Зрозуміло, що традиційним $є$ законодавчий підхід визначення моменту переходу права власності моментом передачі речі, однак у нас він викликає деякі зауваження щодо його коректності.

Спершу звернемося до семантичного аналізу слів «передача», «передавати». Під словом «передавати» словник української мови розуміє 1) віддавати, подавати, вручати кому-небудь те, що тримають у руках або беруть у руки; 2) віддавати що-небудь своє, від себе і т. ін. у чиєсь відання, володіння; а передача - дія за значенням передавати, передати [10, с. 163]. Отже, буквальний сенс поняття «передача», «передання» вказує на те, що воно $\epsilon$ відображенням дії тільки однієї сторони.

Аналогічний підхід до розуміння такого поняття проявляється у вітчизняного законодавця, про що свідчить аналіз деяких нормативних положень. 
Скажімо, ч. 2 ст. 597-1111 ЦК України встановлює, що передача права власності на об'єкт довірчої власності у випадку, встановленому частиною першою цієї статті, здійснюється згідно з актом приймання-передачі, який підписується довірчим власником та особою, якій передається об'єкт довірчої власності. Тобто законодавець розцінює приймання та передачу як різні, самостійні, не ідентичні акти поведінки. Самостійними категоріями вони розглядаються і в контексті визначення договору купівлі-продажу, за яким одна сторона (продавець) передає або зобов'язується передати майно (товар) у власність другій стороні (покупцеві), а покупець приймає або зобов'язується прийняти майно (товар) і сплатити за нього певну грошову суму (ч. 1 ст. 655 ЦК України).

У підсумку констатуємо, що семантично «передання» та «прийняття» речі $\epsilon$ різнонаповненими, тому цілком логічно законодавець розглядає акти передачі та прийняття взаємозумовленими поведінковими актами, проте із самостійним характером кожного. Такий підхід зумовлює постановку питання щодо коректності приурочення моменту переходу права власності тільки до акту передачі речі (односторонньою дією), нівелюючи юридичне значення зворотного акту контрагента - iї прийняття.

У зв'язку з викладеним видається виваженим підхід законодавця до визначення моменту переходу права власності за договором дарування, за якого відбувається зміщення акцентів і момент переходу права власності приурочується не до моменту передання майна дарувальником, а до моменту його прийняття обдарованим. Так, відповідно до ч. 1 ст. 722 ЦК України за договором дарування право власності набувається обдарованим з моменту прийняття ним майна (дарунка). Вбачаємо, що вказаний підхід заслуговує запровадження й до інших договорів, спрямованих на перехід права власності на безоплатній основі.

Продовжуючи думку з приводу сумнівності приурочення моменту переходу права власності до передачі речі, відзначимо, що це викликає i низку практичних проблем, особливо під час аналізу оплатних договорів. Адже чи можна вважати, що відбувся перехід права власності, якщо припустимо, що за договором купівлі-продажу продавець передав покупцеві річ і він ії прийняв, проте покупець не виконав свої зустрічні зобов'язання щодо оплати відповідного товару. Відповідь буде позитивною, якщо без прив'язки до конкретної ситуації ми звернемося до ч. 1 ст. 334 ЦК України. Проте, якщо розглянути вказану ситуацію під іншим ракурсом, відповідь може бути і негативною. Так, згідно зі ст. 692 ЦК України, покупець зобов'язаний оплатити товар після його прийняття або прийняття товаророзпорядчих документів на нього, якщо договором або актами цивільного законодавства не встановлений інший строк оплати товару. У разі неоплати товару покупцем законодавець передбачає низку можливостей для продавця, які в підсумку можуть привести до анулювання у покупця права власності, зокрема шляхом його відмови від договору. Отже, робимо висновок, що важливим для законодавця стає не тільки факт передання речі (його момент) однією стороною, а й факт отримання зустрічного задоволення іншою стороною. Тільки за таких умов можна вважати, що договір, який спрямований на оплатний перехід права власності (нині договір купівлі-продажу), $є$ виконаним. Як пише Ю.В. Шибаєва, поява традиції як моменту, з яким пов'язаний перехід права власності, $\epsilon$ явищем вторинним, пов'язаним з питаннями доказування відносин щодо переходу права власності, а сама традиція в такому сенсі $\epsilon$ лише зовнішнім символом відносин, які складаються, але не їх завершенням [3, с. 51-52].

Основоположне значення в механізмі переходу права власності відіграє договір, якщо ж прив'язувати момент переходу права власності на річ з їі передачею відчужувачем - елементом виконання договору (в консенсуальних договорах) або ж частиною складного юридичного складу реального договору, то незаслужено поза увагою залишається зустрічний елемент виконання договору контрагентом (в оплатних договорах). Обґрунтовував позицію вдалості прив'язки моменту переходу права власності за договором не до моменту укладення відповідного договору, а до його виконання ще Г.Ф. Шершеневич, який указував, що «продавець зберігає право на продану річ до передачі і тому може знову продати їі і тим самим позбавити покупця набутого права, надаючи йому право вимагати винагороди». Доводячи виваженість викладеної позиції, науковець пояснював, що якщо допустити, що право власності переходить у момент укладення договору, а не передачі речі, то насправді проблем буде більше i вони матимуть складніший характер, адже продавець може знову продати річ і хоча тоді цей другий договір буде недійсним, постраждає уже другий покупець. Проте легше першому покупцю запобігти подібному збігу прав набуття володіння, ніж другому зібрати відомості про належність речі, яка набувається [11, с. 180-181]. 
Про практичну вдалість закріплення умови про перехідправавласності на товари до покупця тільки після їх оплати на прикладі договору поставки відзначає М.Л. Пятов, який пише, що покупець, фактично отримавши товари, до моменту оплати не матиме права жодним чином використовувати їх у своїй діяльності, тобто продати, використовувати у виробництві продукції і т. п. При цьому він буде нести перед власником зобов'язання щодо забезпечення збереження цих товарів, i, відповідно, витрати щодо їх зберігання. У цих умовах покупцеві буде абсолютно невигідно «затягувати з оплатою». Отже, така умова буде служити продавцеві додатковим і досить ефективним гарантом своєчасного виконання зобов'язання покупця з оплати товарів. 3 іншого боку, стверджує науковець, умова про момент переходу права власності «з оплатою» може розглядатися і як забезпечення додаткових гарантій для покупця в разі, якщо товари оплачуються покупцем попередньо (до їх передачі). У цій ситуації незалежно від того, що на момент оплати товарів вони продовжують фізично знаходитися на складі продавця, вони переходять у власність покупця. Будучи володільцем товарів, що перейшли у власність покупця, продавець несе відповідальність перед покупцем за збереження цих цінностей і несе витрати щодо їх зберігання. Відповідна умова, на думку дослідника, робить необхідним для продавця мати відповідні товари в наявності на складі на момент отримання платежу, виступає додатковою гарантією своєчасного виконання продавцем своїх зобов'язань щодо передачі товару, невиконання яких стає тут максимально невигідним для продавця [12].

Отже, для оплатних договорів актуальності набуває елемент зустрічного виконання (еквівалентності, проте не тотожності), що цілком відображає сутність оплатних договорів як товарообмінних актів, де у відповідь на благо, яке надається, зустрічно отримується інше благо в такій же або іншій формі. В ключі викладеного заслуговує на увагу та схвалення визначення моменту переходу права власності для договору міни, яким визнається згідно з ч. 4 ст. 715 ЦК України момент одночасного виконання зобов'язань щодо передання майна обома сторонами, якщо інше не встановлено договором або законом. Тому перехід права власності на обмінювані товари відбудеться в момент зустрічного виконання сторонами договору міни своїх зобов'язань за ним. Підтримуємо і законодавчий підхід, відображений у вищезгаданій ч. 6 ст. 25 Законі України «Про приватизацію державного та комунального майна», який теж зумовлює перехід права власності на об'єкт приватизації до покупця сплатою вартості об'єкта продажу (зустрічним виконанням).

Навіть запеклі прихильники системи традиції, приміром B.I. Синайський, теж відзначали, що загальним правилом припинення права власності у разі купівлі-продажу в низці випадків (наприклад, на торгах) слід вважати не тільки «момент передачі покупки», а й сплату сповна запропонованої суми [13, с. 242]. Видається, що вказаний момент (зумовленість переходу права власності не односторонньою дією - переданням, а здійсненням зустрічного взаємозумовленого виконання за договором контрагентом) повинен стати універсальним для всіх оплатних договорів, спрямованих на перехід права власності, а не становити винятки із загального правила.

Висновки. Нині назріла потреба внесення змін у наявну систему визначення моменту договірного переходу права власності, яка потребує зміщення акцентів з моменту передачі речі на момент іï прийняття (в безоплатних договорах) та на момент отримання зустрічного задоволення контрагентом за оплатним договором (наприклад, оплата ціни за придбану річ, отримання речі взамін на іншу річ за договором міни тощо), що цілком відповідатиме сутності та значенню цивільного договору як основоположної підстави переходу права власності, сприятиме удосконаленню юридичної практики шляхом уникнення проблем, зумовлених переходом права власності до моменту отримання зустрічного задоволення іншою стороною та суперечок, пов'язаних з доведенням факту передачі речі і переходу права власності.

\section{Література}

1. Ходырев П.М. Понятие и виды оснований возникновения права собственности. Вестник Удмуртского университета. Правоведение. 2007. № 6. С. 57-62.

2. Щипанова 0.0. Тлумачення змісту статті 334 ЦК України щодо визначення моменту набуття права власності на річ за договором. Правова освіта та правова наука в умовах сучасних трансформаційних процесів : матеріали Всеукраїнської науковопрактичної конференції. Запоріжжя, 2017. С. 42-43.

3. Шибаева Ю.В. Приобретение права собственности по договору : автореф. дисс. ... канд. юрид. наук : 12.00.03. Волгоград, 2003. 199 с.

4. Забелова Л.Б., Ястребов Д.А. Основы правового регулирования договора международной купли-продажи товаров. Москва : ПОЛТЕКС, 2009. 76 c. 
5. Гражданское и торговое право зарубежных государств : учебник / Отв. ред. Е.А. Васильев, А.С. Комаров. 4-е изд., перераб. и доп. В 2-х т. Т. II. Москва : Междунар. отношения, 2008. 560 с.

6. Советское гражданское право. Т. 1 / Под ред. Д.М. Генкина. Москва : Госюриздат, 1950. 495 с.

7. Новицкий И.Б. Сделки. Исковая давность. Москва : Государственное издательство юридической литературы, 1954. 248 с.

8. Сурженко О.А. Засоби фіксації переходу права власності за договором. Теорія і практика правознавства. 2013. Вип. 2. URL: http://nbuv.gov.ua/ UJRN/tipp_2013_2_9.

9. Про приватизацію державного і комунального майна : Закон України від. 18.01.2018 р. Відомості Верховної Ради (ВВР). 2018. № 12. Ст. 68.

10. Словник української мови: в 11 т. / редкол. : І.К. Білодід та ін. Київ : Наук. думка, 1970-1980.
Т. 6 : П-Поїти / ред. А.В. Лагутіна, К.В. Ленець. 1975. 832 c.

11. Шершеневич Г.Ф. Учебник русского гражданского права (по изданию 1907 г.). Москва : Фирма «СПАРК», 1995. 556 с.

12. Пятов M.І. Момент перехода права собственности как элемент договорной политики. URL: http://www.buh.ru.

13. Синайский В.И. Русское гражданское право. Москва : Статут, 2002. 638 с.

Гудима М. М., кандидат юридичних наук, доцент, докторант кафедри цивільного права Навчально-наукового юридичного інституту Прикарпатського національного університету імені Василя Стефаника 